\title{
Detection of emerging antibiotic resistance in bacteria isolated from subclinical mastitis in cattle in West Bengal
}

\author{
Arnab Das ${ }^{1}$, Chanchal Guha², Ujjwal Biswas², Partha Sarathi Jana², Amaresh Chatterjee ${ }^{2}$ and Indranil Samanta ${ }^{3}$
}

1. Animal Resources Development Department, Institute of Animal Health and Veterinary Biologicals, Government of West Bengal, Kolkata, West Bengal, India; 2. Department of Veterinary Epidemiology and Preventive Medicine, Faculty of Veterinary and Animal Sciences, West Bengal University of Animal and Fishery Sciences, Kolkata, West Bengal, India; 3. Department of Veterinary Microbiology, Faculty of Veterinary and Animal Sciences, West Bengal University of Animal and Fishery Sciences, Kolkata, West Bengal, India.

Corresponding author: Indranil Samanta, e-mail: isamanta76@gmail.com,

Co-authors: AD: drarnab.vet@gmail.com,CG: profcguha@gmail.com, UB: ujjalbiswas.2007@rediffmail.com, PSJ: drjana2012@rediffmail.com, AC: dramareshchatterjee9@gmail.com

Received: 05-12-2016, Accepted: 31-03-2017, Published online: 12-05-2017

doi: 10.14202/vetworld.2017.517-520 How to cite this article: Das A, Guha C, Biswas U, Jana PS, Chatterjee A, Samanta I (2017) Detection of emerging antibiotic resistance in bacteria isolated from subclinical mastitis in cattle in West Bengal, Veterinary World, 10(5): 517-520.

\begin{abstract}
Aim: The aim of this work was to detect antibiotic resistance in Gram-negative bacteria isolated from subclinical mastitis in cattle in West Bengal.

Materials and Methods: The milk samples were collected from the cattle suffering with subclinical mastitis in West Bengal. The milk samples were inoculated into the nutrient broth and incubated at $37^{\circ} \mathrm{C}$. On the next day, the growth was transferred into nutrient agar and MacConkey agar. All the pure cultures obtained from nutrient agar slant were subjected to Gram-staining and standard biochemical tests. All the bacterial isolates were tested in vitro for their sensitivity to different antibiotics commonly used in veterinary practices. All Gram-negative isolates including positive

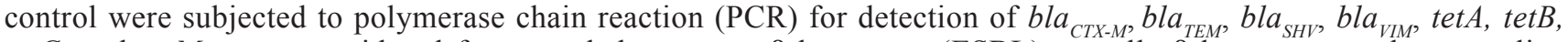
tet $C$, and tet $M$ genes considered for extended-spectrum $\beta$-lactamase (ESBL), metallo- $\beta$-lactamase, and tetracycline resistance.

Results: In total, 50 Gram-negative organisms (Escherichia coli, Proteus, Pseudomonas, Klebsiella, and Enterobacter) were isolated from milk samples of subclinical mastitis infected cattle. Among these Gram-negative isolates, 48\% (24/50) were found either ESBL producing or tetracycline resistant. Out of total 50 Gram-negative isolates, bla $a_{C T X-M}$ was detected in $18(36 \%)$ isolates, and $6(12 \%)$ harbored $b l a_{T E M}$ genes in PCR. None of the isolates carried bla $a_{S H V}$ genes. Further, in this study, $5(10 \%)$ isolates harbored $\operatorname{tet}(A)$ gene, and $8(16 \%)$ isolates carried tet $(B)$ gene. No tet $(C)$ gene was detected from the isolates.
\end{abstract}

Conclusion: This study showed emerging trend of antibiotic-resistant Gram-negative bacteria associated with subclinical mastitis in cattle in West Bengal, India.

Keywords: antibiotic resistance, cattle, Escherichia coli, India, sub-clinical mastitis.

\section{Introduction}

Subclinical mastitis is the most fatal infection confronted by the dairy industry today with significant economic losses worldwide including India [1]. It also poses a major public health risk due to transmission possibility of zoonotic bacteria or their toxin along with antibiotic resistance genes [2]. Most of the subclinical mastitic animals do not produce characteristic symptoms of mastitis and are persistent shedder of zoonotic bacteria without adequate awareness of farmers regarding the transmission possibility [3].

Subclinical mastitis is considered to have a multifactorial etiology including several groups of

Copyright: Das, et al. Open Access. This article is distributed under the terms of the Creative Commons Attribution 4.0 International License (http://creativecommons.org/licenses/by/4.0/), which permits unrestricted use, distribution, and reproduction in any medium, provided you give appropriate credit to the original author(s) and the source, provide a link to the Creative Commons license, and indicate if changes were made. The Creative Commons Public Domain Dedication waiver (http://creativecommons.org/ publicdomain/zero/1.0/) applies to the data made available in this article, unless otherwise stated. microorganisms such as bacteria, virus, fungi, yeast, and algae [4]. Among the Gram-negative bacterial etiological agents, the major group includes coliform bacteria (Escherichia coli, Enterobacter, Klebsiella), Pseudomonas and Serratia [5].

Early detection of subclinical mastitis and dry cow therapy with proper antibiotics, use of post-milking teat disinfectants and effective pre-milking hygiene becomes relevant to minimize economic losses in dairy farms and to prevent zoonotic transmission [6]. However, the etiological and commensal bacteria present in animals and exposed to the antimicrobial pressure, develop survival strategies through evolutionary adaptations [7]. Gram-negative bacteria specially Enterobacteriaceae organisms mostly produce $\beta$-lactamase enzymes to prevent the action of $\beta$-lactam antibiotics. There are more than $1000 \beta$-lactamase enzymes that can be classified under four main classes, i.e., A-D [8]. The most clinically important Class A enzymes, found in Enterobacteriaceae, are known as extended-spectrum 
$\beta$-lactamases (ESBLs). It can confer resistance to a variety of $\beta$-lactam antibiotics, including penicillins, $2^{\text {nd }}, 3^{\text {rd }}$ and $4^{\text {th }}$-generation cephalosporins and monobactams (e.g., aztreonam), but usually not the carbapenems or the cephamycins (e.g., cefoxitin). There are three classical ESBLs, i.e., TEM (except TEM-1), SHV (except SHV-1 and 2), and CTX-M [9]. Among them, CTX-M is observed as the most prevalent type worldwide [10]. Other than ESBL genes, possession of tetracycline resistance gene is also common in Gram-negative bacteria [11].

In India, subclinical mastitis in cattle and buffaloes caused by Gram-positive bacteria such as Staphylococcus spp. are reported from different states such as Karnataka, Punjab, and others [3,12]. However, etiological correlation of Gram-negative bacteria with subclinical mastitis in Indian cattle is less explored. This study was conducted to know the occurrence of Gram-negative bacteria in subclinical mastitis in cattle associated with antibiotic resistance potential.

\section{Materials and Methods}

\section{Ethical approval}

The study was approved by Instituional Animal Ethics Committee, WBUAFS.

\section{Sampling}

The udders of the suspected animals were examined for fibrosis, inflammatory swellings, visible injury, tick infestation, atrophy of the tissue, and swelling of supramammary lymph nodes. The size and consistency of mammary quarters were inspected for the presence of any abnormalities, such as disproportional symmetry, swelling, firmness, and blindness. Information relating to the previous health history of the mammary quarters and causes of blindness was obtained from the owners of the farm. The mastitic milk was collected aseptically as described earlier [13]. The collected milk samples were transported to the laboratory maintaining the cold chain.

\section{Isolation of Gram-negative bacteria}

Initially, the milk samples were inoculated into the nutrient broth (HiMedia, India) and incubated at $37^{\circ} \mathrm{C}$. On the next day, the growth was transferred into nutrient agar and MacConkey agar (HiMedia, India). The convex glistening single colonies with greenish discolouration in nutrient agar and the pink and pale colored colonies in MacConkey agar were isolated into nutrient agar slant as a pure culture. All the pure cultures obtained from nutrient agar slant were subjected to Gram-staining and standard biochemical tests as described earlier [14].

\section{Antibiotic sensitivity test}

All the bacterial isolates were tested in vitro for their sensitivity to different antibiotics commonly used in veterinary practices. The antibiotic disks oxytetracycline, amikacin, gentamicin, amoxicillin and clavulanic acid, amoxicillin sulbactam, ceftriaxone and sulbactam, ceftriaxone and tazobactam, enrofloxacin, ceftriaxone and cefotaxime (HiMedia) were selected for the study. The interpretation was done in accordance to performance standards for antimicrobial disks susceptibility tests, Clinical Laboratory Standard Institute [15].

\section{Polymerase chain reaction (PCR)-based detection of ESBL and tetracycline resistance genes}

For PCR-based detection of major ESBL genes (bla $\left.{ }_{T E M}, b l a_{S H V}, b l a_{C T X-M}\right)$ and tetracycline resistance $(\operatorname{tet}(A)$,tet $(B)$ and $\operatorname{tet}(C))$ genes from all the bacterial isolates, DNA was extracted as per the method described by Bonnet et al. [16]. All Gram-negative isolates including positive control were subjected to PCR for detection of bla $a_{C T X-M}$, bla $_{T E M}$, bla $_{S H V}$, bla $_{V I M}$, tet $A$, tet $B$, tet $C$, and tet $M$ genes considered for ESBL, metallo- $\beta$-lactamase, and tetracycline resistance. The PCR was performed in a thermocycler (BioRad, USA) with the primers (Imperial life sciences, India) and the cycle conditions as described earlier [16].

\section{Results}

In this study, 50 Gram-negative organisms (E. coli, Proteus, Pseudomonas, Klebsiella, and Enterobacter) were isolated from milk samples of subclinical mastitic cattle. Among these Gramnegative isolates, 48\% (24/50) isolates were detected phenotypically as either ESBL producing or tetracycline resistant in antibiotic sensitivity test.

Out of total 50 Gram-negative isolates, bla ${ }_{C T X-M}$ was detected in $18(36 \%)$ isolates, and $6(12 \%)$ harbored bla ${ }_{\text {TEM }}$ genes in PCR (Figures-1 and 2). None of

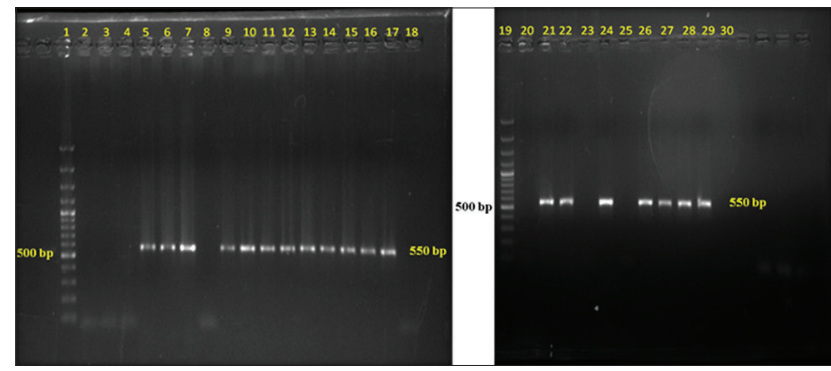

Figure-1: Gel electrophoresis image of polymerase chain reaction amplified products of bla $a_{C T X-M}$ gene of Gramnegative isolates; Lane 1 - 1500 bp DNA ladder; Lane 2-14, 16-19 - Isolated Escherichia coli samples; Lane 15 - Positive control for bla ${ }_{C T X-M}$ gene; Lane 20 - Negative control.

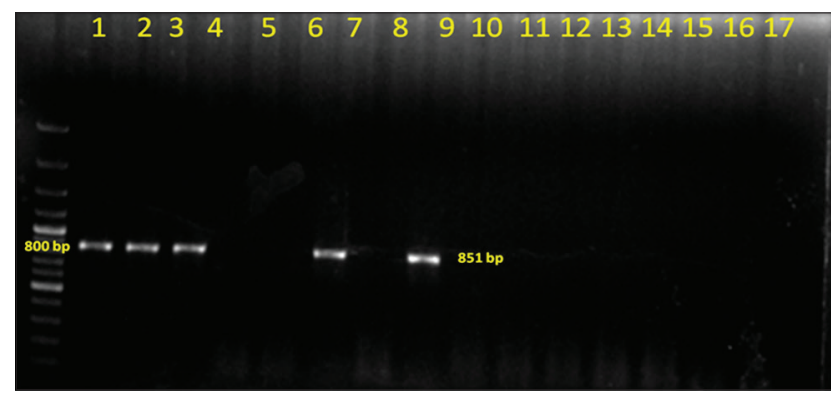

Figure-2: Gel electrophoresis image of polymerase chain reaction amplified products of bla ${ }_{T E M}$ gene of Gramnegative isolates; Lane 1 - 1500 bp DNA ladder; Lane 2-8, 10-16 - Isolated Escherichia coli samples; Lane 15 - Positive control for bla ${ }_{T E M}$ gene; Lane 20 - Negative control. 
the isolates carried $b l a_{S H V}$ genes. Further, in this study, $5(10 \%)$ isolates harbored $\operatorname{tet}(A)$ gene and $8(16 \%)$ isolates carried tet $(B)$ gene (Figures-3 and 4$)$. No tet $(C)$ gene was detected in the isolates.

\section{Discussion}

Subclinical mastitis is the most fatal infection confronted by dairy industry today with significant economic losses worldwide including India [1]. Moreover, with the extensive use of $\beta$-lactam antibiotics, cattle and other ruminants represent a considerable source for the transmission of antibiotic resistance genes (e.g., ESBL) or antibiotic resistant strains to the human intestinal bacterial flora [17]. This study was conducted to know the occurrence of Gram-negative bacteria in subclinical mastitis in cattle associated with antibiotic resistance potential.

Among these Gram-negative isolates, 48\% $(24 / 50)$ were either ESBL producing or tetracycline resistant in this study. Earlier reports from different countries revealed the lower prevalence of ESBLproducing Enterobacteriaceae isolates (0.4-13\%) associated with bovine mastitis [18-20]. In India, few reports are available regarding detection of ESBL/ New Delhi metallo- $\beta$-lactamase-producing $E$. coli in milk samples collected from clinical or subclinical mastitic cattle $[17,21]$. The prevalence study of ESBL-producing Gram-negative bacteria with substantial numbers of mastitic milk samples is not apparently available in India to compare the present finding.

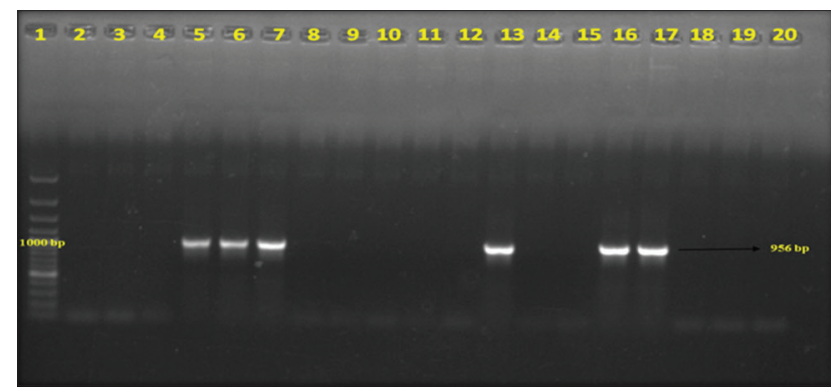

Figure-3: Gel electrophoresis image of polymerase chain reaction amplified products of tet $A$ gene of Gramnegative isolates; Lane 1 - 1500 bp DNA ladder; Lane 2-16, 18-19 - Isolated Escherichia coli samples; Lane 17 - Positive control for tetA gene; Lane 20 - Negative control.

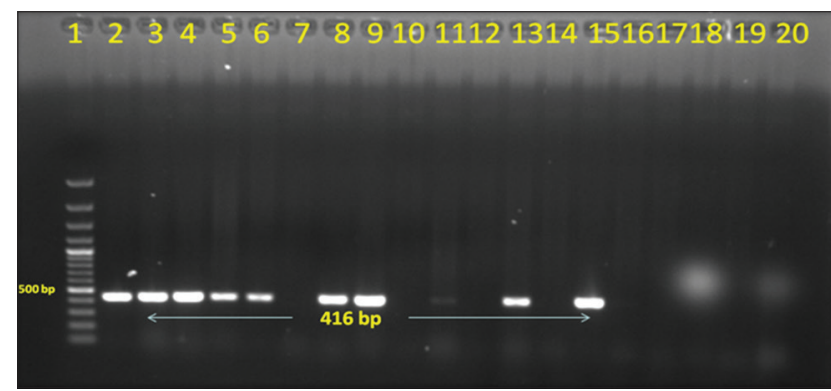

Figure-4: Gel electrophoresis image of polymerase chain reaction amplified products of tet $B$ gene of Gramnegative isolates. Lane 1 - 1500 bp DNA ladder; Lane 2-14, 16-19 - Isolated Escherichia coli samples; Lane 15 - Positive control for tetB gene; Lane 20 - Negative control.
However, the study indicates about alarming rise in the occurrence of ESBL-producing Gram-negative isolates in subclinical mastitic cattle.

Out of total 50 Gram-negative isolates, bla ${ }_{C T X-M}$ was detected in $18(36 \%)$ isolates, and $6(12 \%)$ harbored bla $_{T E M}$ genes in PCR. None of the isolates carried bla $_{S H V}$ genes. At present, CTX-M is the major ESBL enzyme produced by different clonal complexes of Enterobacteriaceae which mostly replaced the SHV and TEM-type ESBLs during the last decade [22]. It was also observed that CTX-M and TEM were the most prevalent bla-encoded enzyme in human clinical isolates worldwide [23-25]. As well as, CTX-M ESBL producing Klebsiella pneumonae was also isolated from the cases of bovine mastitis [26].

Further, in this study, $5(10 \%)$ isolates harbored tet( $A)$ gene and $8(16 \%)$ isolates carried tet(B) gene. No tet $(C)$ gene was detected from the isolates. Earlier studies indicated the presence of tet genes in Gramnegative bacteria isolated from bovine mastitis and other infections [27,28].

\section{Conclusion}

The present study showed emerging trend of antibiotic resistant gram negative bacteria associated with sub-clinical mastitis in cattle in West Bengal, India.

\section{Authors' Contributions}

AD: Conducted study. CG, UB, PSJ, AC and IS: Planned the study. AD and IS: Drafted and revised the manuscript. All authors read and approved the final manuscript.

\section{Acknowlegments}

The authors provide sincere gratitude to honorable Vice Chancellor, West Bengal University of Animal and Fishery Sciences, Kolkata for necessary infrastructures.

\section{Competing Interests}

The authors declare that they have no competing interests.

\section{References}

1. Joshi, G. (2006) Status of mastitis as an emerging disease in improved and periurban dairy farms in India. Ann. N. Y. Acad. Sci., 10: 1373-3177.

2. Ibrahim, H.M.M., Ahmed, A.M., El-seedy, Y.Y. and El-Khodery, S.A. (2015) Distribution of multidrug-resistant gram negative bacteria causing clinical mastitis in dairy cows. Glob. Vet., 15: 268-277.

3. Prabhu, K.N., Isloor, S., Hegde, R., Rathnamma, D., Veeregowda, B.M., Narasimha Murthy, H.N., Shome, R. and Suryanarayana, V.V.S. (2013) Development of polymerase chain reaction for detection of predominant streptococcal isolates causing sub clinical bovine mastitis. Indian J. Biotechnol., 12: 208-212.

4. Mallikarjunaswamy, M.C. and Krishnamurthy, G.V. (1997) Antibiogram of bacterial pathogens isolated from bovine sub-clinical mastitis cases. Indian Vet. J., 74: 885-886.

5. Samanta, I. (2013) Veterinary Bacteriology. $1^{\text {st }}$ ed. New India Publishing Agency, New Delhi, India. 
6. Idriss, S.E., Foltys, V., Tančin, V., Kirchnerová, K., Tančinová1, D. and Zaujec, K. (2014) Mastitis pathogens and their resistance against antimicrobial agents in dairy cows in Nitra, Slovakia. Slovak J. Anim. Sci., 47: 33-38.

7. Allen, H.K. and Stanton, T.B. (2014) Altered egos: Antibiotic effects on food animal micro biomes. Ann. Rev. Microbiol., 68: 297-315.

8. Bush, K. and Jacoby, G.A. (2010) Updated functional classification of beta-lactamases. Antimicrob. Agents Chemother. 54: 969-976.

9. EFSA Panel on Biological Hazards. (2011) Scientific opinion on the public health risks of bacterial strains producing extended-spectrum $\beta$-lactamases and/or AmpC $\beta$-lactamases in food and food-producing animals. EFSA J., 9: 2322.

10. Carattoli, A. (2013) Plasmids and the spread of resistance. Int. J. Med. Microbiol., 303: 298-304.

11. Wellington, E.M.H., Boxall, A.B.A., Cross, P., Feil, E.J., Gaze, W.H., Hawkey, P.M., Johnson-Rollings, A.S., Jones, D.L., Lee, N.M., Otten, W., Thomas, C.M. and Williams, A.P. (2013) The role of the natural environment in the emergence of antibiotic resistance in Gram-negative bacteria. Lancet Infect. Dis., 13: 155-165.

12. Kaur, M., Ramneek, Bansal, B.K., Mukhopadhyay, C.S. and Arora, J.S. (2015) Status of sub-clinical mastitis and associated risk factors in Indian water buffalo in Doaba region of Punjab, India. Indian J. Dairy Sci., 68: 483-487.

13. Schalm, O.W., Carroll, E.J. and Jain, N.C. (1971) Bovine Mastitis. Lea and Febiger, Philadelphia.

14. Quinn, P.J., Carter, M.E., Markey, B.K. and Carter, G.R. (1994) Clinical Veterinary Microbiology. Mosby, UK.

15. CLSI. (2010) Performance standards for antimicrobial disk and dilution susceptibility tests for bacteria isolated from animals: Approved standard. $3^{\text {rd }}$ ed. M31-A3. CLSI, Wayne, PA. p13-23.

16. Bonnet, R., Recule, C., Baraduc, R., Chanal, C., Sirot, I., De Champs, C. and Sirot, J. (2003) Effect of D240G substitution in a novel ESBL CTX-M-27. J. Antimicrob. Chemother., 52: 29-35.

17. Bandyopadhyay, S., Samanta, I., Bhattacharyya, D., Nanda, P.K., Kar, D., Chowdhury, J., Dandapat, P., Das, A.K., Batul, N., Mondal, B., Dutta, T.K., Das, G., Das, B.C., Naskar, S., Bandyopadhyay, U.K., Das, S.C. and Bandyopadhyay, S. (2015) Co-infection of methicillin-resistant Staphylococcus epidermidis, methicillin-resistant Staphylococcus aureus and extended spectrum $\beta$-lactamase producing Escherichia coli in bovine mastitis - Three cases reported from India. Vet. Q., 35: 56-61.

18. Hu, G.Z., Kuang, X.H., Yuan, L., Mo, J., Pan, Y.S., Fu, X.L., Xu, K.L. and Li, L.F. (2006) Detection of antibiotic susceptibility of ESBL producer Enterobacteriaceae against
21 agents. Zhongguo Ren Shou Gong Huan Bing Za Zhi., 22: 884-887.

19. Dahmen, S., Métayer, V., Gay, E., Madec, J.Y. and Haenni, M. (2013) Characterization of extended-spectrum beta-lactamase (ESBL)-carrying plasmids and clones of Enterobacteriaceae causing cattle mastitis in France. Vet. Microbiol., 162: 793-799.

20. Freitag, C., Michael, G.B., Kadlec, K., Hassel, M. and Schwarz, S. (2016) Detection of plasmid-borne extended-spectrum $\beta$-lactamase (ESBL) genes in Escherichia coli isolates from bovine mastitis. Vet. Microbiol. (In Press).

21. Ghatak, S., Singha, A., Sen, A., Guha, C., Ahuja, A., Bhattacharjee, U., Das, S., Pradhan, N.R., Puro, K., Jana, C., Dey, T.K., Prashantkumar, K.L., Das, A., Shakuntala, I., Biswas, U. and Jana, P.S. (2013) Detection of New Delhi metallo-beta-lactamase and extended-spectrum beta-lactamase genes in Escherichia coli isolated from mastitic milk samples. Transbound. Emer. Dis., 60: 385-389.

22. Cantón, R. and Coque, T.M. (2006) The CTX-M $\beta$-lactamase pandemic. Curr. Opin. Microbiol., 9: 466-475.

23. Carattoli, A., Garcia-Fernandez, A., Varesi, P., Fortini, D., Gerardi, S., Penni, A., Mancini, C. and Giordano, A. (2008) Molecular epidemiology of Escherichia coli producing extended-spectrum $\beta$-lactamases isolated in Rome, Italy. J. Clin. Microbiol., 46: 103-108.

24. Kiratisin, P., Apisarnthanarak, A., Laesripa, C. and Saifon, P. (2008) Molecular characterization and epidemiology of extended-spectrum $\beta$ - lactamase-producing Escherichia coli and Klebsiella pneumonia isolates causing health care-associated infection in Thailand, where the CTX-M family is endemic. Antimicrob. Agents Chemother, 52: $2818-2824$

25. Smet, A., Martel, A., Persoons, D., Dewulf, J., Heyndrickx, M., Catry, B., Herman, L., Haesebrouck, F. and Butaye, P. (2008) Diversity of extended-spectrum $\beta$-lactamases and Class $\mathrm{C} \beta$-lactamases among cloacal Escherichia coli isolates in Belgian broiler farms. Antimicrob. Agents Chemother., 52: 1238-1243.

26. Locatelli, C., Licia, S., Giuliano, P. and Paolo, M. (2010) CTX-M1 ESBL-producing Klebsiella pneumoniae sub sp. pneumoniae isolated from cases of bovine mastitis. J. Clin. Microbiol., 48: 3822.

27. Ahmed, A.M. and Shimamoto, T. (2011) Molecular characterization of antimicrobial resistance in Gram negative bacteria isolated from bovine mastitis in Egypt. Microbiol. Immunol., 55: 318-327.

28. Card, R., Zhang, J., Das, P., Cook, C., Woodford, N. and Anjum, M.F. (2013) Evaluation of an expanded microarray for detecting antibiotic resistance genes in a broad range of gram-negative bacterial pathogens. Antimicrob. Agents Chemother., 57: 458-465. 